\title{
Algal polysaccharide's potential to combat respiratory infections caused by Klebsiella pneumoniae and Serratia marcescens biofilms
}

\author{
Jyoti Vishwakarma ${ }^{1} \cdot$ Bhumika Waghela $^{1} \cdot$ Berness Falcao $^{1} \cdot$ Sirisha L. Vavilala ${ }^{1}$ \\ Received: 9 March 2021 / Accepted: 12 July 2021 / \\ Published online: 27 August 2021 \\ (C) The Author(s), under exclusive licence to Springer Science+Business Media, LLC, part of Springer Nature 2021
}

\begin{abstract}
The growth of respiratory diseases, as witnessed through the SARS and COVID-19 outbreaks, and antimicrobial-resistance together pose a serious threat to humanity. One reason for antimicrobial resistance is formation of bacterial biofilms. In this study the sulphated polysaccharides from green algae Chlamydomonas reinhardtii (Cr-SPs) is tested for its antibacterial and antibiofilm potential against Klebsiella pneumoniae and Serratia marcescens. Agar cup assay clearly indicated the antibacterial potential of Cr-SPs. Minimum inhibitory concentration $\left(\mathrm{MIC}_{50}\right)$ of $\mathrm{Cr}$-SPs against Klebsiella pneumoniae was found to be $850 \mu \mathrm{g} / \mathrm{ml}$, and it is $800 \mu \mathrm{g} / \mathrm{ml}$ in Serratia marcescens. Time-kill and colony-forming ability assays suggest the concentration-dependent bactericidal potential of Cr-SPs. Cr-SPs showed $74-100 \%$ decrease in biofilm formation in a concentration-dependent manner by modifying the cell surface hydrophobic properties of these bacteria. Cr-SPs have also distorted preformed-biofilms by their ability to interact and destroy the extra polymeric substance and eDNA of the matured biofilm. Scanning electron microscopy analysis showed that Cr-SPs effectively altered the morphology of these bacterial cells and distorted the bacterial biofilms. Furthermore reduced protease, urease and prodigiosin pigment production suggest that Cr-SPs interferes the quorum sensing mechanism in these bacteria. The current study paves way towards developing Cr-SPs as a control strategy for treatment of respiratory tract infections.
\end{abstract}

Keywords Algal polysaccharides · Respiratory tract infections (RTIs) - Biofilm inhibition · Biofilm eradication · Quorum sensing interference $\cdot$ Extra polymeric substance (EPS)

Sirisha L. Vavilala

sirisha@cbs.ac.in

Jyoti Vishwakarma

jyoti16594@gmail.com

Bhumika Waghela

bhumikawaghela12@gmail.com

Berness Falcao

bernessfalcao@gmail.com

1 School of Biological Sciences, UM-DAE Centre for Excellence in Basic Sciences, University of Mumbai, Kalina Campus, Vidyanagari, Mumbai 400098, India 


\section{Introduction}

Respiratory diseases are the second-most leading cause of death after cardiovascular diseases [1]. Chronic obstructive pulmonary disease (COPD), asthma, tuberculosis, lung cancer, and lower respiratory tract infections (LTRIs) are the top respiratory diseases that are the most common cause of deaths. They impose a global health burden. Apart from them, there are several respiratory disorders like sleep-disordered breathing, pulmonary hypertension, and occupational lung diseases that are also lethal, but their burden is not well documented [2,3]. The major cause of respiratory infections is pathogenic bacteria. Bacteria that cause respiratory infections are Bacillus spp., Proteus mirabilis, Klebsiella pneumoniae, Serratia marcescens, etc. [4, 5]. If these bacterial infections are left untreated, they can cause serious complications and death. This study focuses on two important respiratory tract infections (RTIs) causing bacteria Klebsiella pneumoniae and Serratia marcescens.

$K$. pneumoniae is a Gram-negative respiratory pathogen prominently present in the mucosal layers of the body. Other than pneumoniae, it also causes other miscellaneous infections such as meningitis, septicaemia, and purulent abscesses [6, 7]. Immunocompromised individuals have higher probability of acquiring K. pneumoniae in the lung, blood (sepsis), urinary tract, liver, and other organs. In these environments, it is extremely hard to eradicate [8]. It is responsible for more than $70 \%$ of infections in humans and, more worryingly, is rapidly developing resistance to multiple antibiotics [9]. One big reason for their ability to survive is attributable to biofilms which assist $K$. pneumoniae resist harsh host environment inside chronically infected patients. Due to the combined threat of multiple virulence factors such as capsular polysaccharides, lipopolysaccharides, urease, outer membrane protein, and adherence factors, $K$. pneumoniae has acquired superbug status and is one of the most common antibiotic-resistant bacteria [9].

Serratia marcescens is another Gram-negative facultative anaerobe belonging to Enterobacteriaceae family. It is classified as an opportunistic pathogen which can grow at temperatures between 30 and $37^{\circ} \mathrm{C}$. It produces a characteristic red pigment known as prodigiosin. It secretes DNAase and other enzymes such as protease and urease. It is a nosocomial pathogen that causes many infections in humans like lower respiratory tract infections, urinary tract infections, bloodstream infection, wound infection, meningitis and ocular infection [10-12]. Serratia marcescens also attained superbug status as it is resistant to many traditional antibiotics like penicillin, ampicillin and those involving fluoroquinolones, aminoglycosides and $\beta$-lactams. The high virulence and resistance of $S$. marcescens biofilms necessitate seeking new treatment strategies $[13,14]$.

Antimicrobials agents such as plant bioactive compounds and synthetic drugs are used for treatment of these infections [15-21]. Inspite of various available treatments, bacteria tend to develop resistance against antibiotics due to numerous reasons such as target modifications, reduce permeability, target protection, horizontal gene transfer, overuse of antibiotics and biofilm formation [22, 23]. Out of these, one of the major reasons is biofilm formation. Bacterial biofilms are major contributors in causing RTIs [6]. Biofilm is an organised structure caused by groups of microorganisms which are encapsulated and protected by extra cellular matrix (ECM) which offers them great resistance to antimicrobial drugs [9]. The ECM layer comprises of DNA, proteins and polysaccharides [6]. The bacteria associated with the biofilm attain the ability to survive in adverse conditions as well as are metabolically slow growing. Therefore, this makes them resistant to various antibiotic treatments as most of the antibiotics are successful in targeting metabolically active cells $[24,25]$. 
Algal derived bioactive compounds have paved way to a new approach to combat biofilms. Algae are known to be reservoirs of polysaccharides which show broad array of biological activities that make them a suitable counterpart of synthetic antibiotics. Sulphated polysaccharides (SPs) are negatively charged molecules with a linear structure and are found in the cell wall of various algal species. The algal SPs have been reported to have various bioactivities such as antioxidant, anti-viral, anticoagulant, anti-allergic, antithrombotic, anti-cancer, antimicrobial, anxiolytic, antinociceptive, anti-obesity and anti-inflammatory activities [26]. Earlier research showed the potential of different types of marine algal SPs such as carrageenan, fucoidan and ulvan from red, brown and green algae as promising antimicrobial agents against a variety of human bacterial pathogens. It was reported earlier that fucoidan F85 from Streptococcus mutans and Streptococcus sorbinus showed complete growth inhibition of both planktonic and biofilm forming dental plaque bacteria [27]. The biological activities of the SPs are attributed to various structural factors such as degree of sulfation, molecular weight, type of sugar moiety attached, sulphate content and glycosidic bonds [28-31]. SPs from green algae Chlamydomonas reinhardtii (CrSPs) have been extracted, purified and are known to possess various biological activities like anti-cancer, antioxidant and neuroprotective agents [32-35]. However, the potential of Cr-SPs to combat biofilms against RTIs causing bacteria is not yet reported. The current study focuses at elucidating the potential of algal polysaccharides (Cr-SPs) against RTIs causing bacterial biofilms.

\section{Materials and Methods}

\section{Microbial Strains and Their Culture Conditions}

The bacterial strains used for the current study K. pneumoniae (MTCC no. 432) and $S$. marcescens (MTCC no. 2645) cultures were procured from Microbial Type Culture Collection and Gene Bank (MTCC), Chandigarh, India. The cultures were allowed to grow and maintained on growth medium-3 (GM-3) liquid broth and $2 \%$ agar and incubated at $37^{\circ} \mathrm{C}, 120 \mathrm{rpm}$.

\section{Algal Source and Growth Conditions}

Chlamydomonas reinhardtii (CC124 strain), freshwater green algae was procured from Chlamydomonas Genetic Centre, USA. Tris-acetate-phosphate medium (TAP) at pH 7 is used to grow and maintain the algal cells. The cells were maintained by sub-culturing them every 4-5 days. For experimental purposes, single colonies from these plates were inoculated in TAP broth media and kept in shaker conditions at a $120 \mathrm{rpm}$ with $300 \mu \mathrm{mol}$ photons $\mathrm{m}^{-2} \mathrm{~s}^{-1}$ illumination [36].

\section{Extraction, Purification and Structural Characterization of Cr-SPs}

C. reinhardtii (CC-124) algal cells were grown in appropriate growth conditions and medium for $72 \mathrm{~h}$. After $72 \mathrm{~h}$ hot water extraction method was employed for the extraction of sulphated polysaccharides (Cr-SPs). The extract is subjected to rotary evaporation followed by purification using anion exchange column chromatography. Then the biochemical 
characterization of these purified Cr-SPs was carried out in order to estimate the carbohydrate, sulphate, uronic acid and protein content of the extract. Carbohydrate content estimation was done using phenol-sulphuric acid method, sulphate content was estimated using barium chloride-gelatin method, and uronic acid content was estimated by modified carbazole method and protein by Bradford's method [33, 37, 38]. The elutes which showed highest carbohydrate and sulphate contents were pooled and used for structural analysis of the extract. Structural characterization by FTIR was performed by preparing a pellet of $5 \mathrm{mg}$ of Cr-SPs with potassium bromide. The infrared spectra were measured from 500 and $4000 \mathrm{~cm}^{-1}$ on a Thermo Nicolet 6700 FTIR spectrophotometer. Further ${ }^{1} \mathrm{H}$ NMR analysis of Cr-SPs was carried out by converting the SPs into monomers by hydrolysing with trifluoroacetic acid. The hydrolysed monomers were dissolved in $0.5 \mathrm{ml}$ of $\mathrm{D}_{2} \mathrm{O}$ and ${ }^{1} \mathrm{H} \mathrm{NMR}$ spectra was taken at $27^{\circ} \mathrm{C}$.

\section{Antimicrobial Properties of Cr-SPs}

\section{Agar Cup Diffusion Assay}

The Kirby-Bauer test also known as the Agar cup method is a plate assay that helps in visually observing the zones of inhibition in the agar plates when a drug is added along with the culture under study. Overnight grown culture of $K$. pneumoniae and $S$. marcescens were taken, and $100 \mu \mathrm{L}$ was spread on GM3 agar plate evenly. Wells in the agar plates were loaded with $100 \mu \mathrm{L}$ of Cr-SPs in a concentration ranging from 0.5 to $32 \mathrm{mg} / \mathrm{mL}$ with appropriate controls and incubated for $24 \mathrm{~h}$ at $37^{\circ} \mathrm{C}$. The antibacterial potential of Cr-SPs was determined by measuring the diameter of zone of inhibition around the wells [39].

\section{Time-Kill Curves}

Time-kill curves were performed to check the potential of the antimicrobial agent to inhibit bacterial growth over time. For this experiment, $10^{10} \mathrm{CFU} / \mathrm{mL}$ diluted overnight cultures were used, and each well had total of $200 \mu \mathrm{L}$ system having $100 \mu \mathrm{L}$ of culture incubated in GM-3 media along with different concentrations of Cr-SPs $(0.5-8 \mathrm{mg} / \mathrm{mL})$ with appropriate controls. Plates were incubated at $37{ }^{\circ} \mathrm{C}$ with orbital shaking at $120 \mathrm{rpm}$. Absorbance at $595 \mathrm{~nm}$ was recorded every half hour from 0 to $48 \mathrm{~h}$, and growth curves were plotted by taking time vs optical density (O.D) [40].

\section{Colony-Forming Unit (CFU) Assay}

This assay helps to check the effect of Cr-SPs on bacterial colony formation ability. Overnight culture of bacterium was diluted to $10^{6} \mathrm{CFU} / \mathrm{mL}$ and treated with Cr-SPs in concentration ranging from 0.5 to $8 \mathrm{mg} / \mathrm{mL}$ for $24 \mathrm{~h}$. After incubation the culture was appropriately diluted, and $50 \mu \mathrm{L}$ were plated on GM-3 agar plates and incubated for $24 \mathrm{~h}$ at $37{ }^{\circ} \mathrm{C}$. After $24 \mathrm{~h}$ the colonies were counted manually, and the data is used for viability analysis [40]. 


\section{Determination of Minimum Inhibitory Concentration (MIC) and Minimum Bactericidal Concentration (MBC)}

The minimum concentration at which Cr-SPs inhibit the growth of $K$. pneumoniae and $S$. marcescens was determined using the modified 3-(4,5-dimethylthiazol-2-yl)-2,5-diphenyl tetrazolium bromide (MTT) method [41]. Overnight grown culture were adjusted to $10^{6} \mathrm{CFU} / \mathrm{mL}$ and treated with varying concentrations of Cr-SPs for $24 \mathrm{~h}$ at $37^{\circ} \mathrm{C}$ with appropriate controls. Post incubation, the cells were washed twice with phosphate-buffered saline (PBS) and subjected to 3-(4,5-dimethylthiazol-2-yl)-2,5-diphenyl tetrazolium bromide (MTT; $20 \mu \mathrm{g} / \mathrm{mL}$ ) treatment for $3 \mathrm{~h}$. After $3 \mathrm{~h}$ the cells were washed with PBS, and the formazan crystals formed were dissolved in $100 \mu \mathrm{l}$ of dimethylsulphoxide (DMSO), and absorbance reading was taken at $570 \mathrm{~nm}$. The bacterial viability is determined by plotting the concentration vs percentage viability [42].

MBC assay helps to determine if Cr-SPs has bactericidal activity in these bacteria. As described above, $10^{6} \mathrm{CFU} / \mathrm{mL}$ of bacterial cultures was subjected to varying concentrations of Cr-SPs treatment for $24 \mathrm{~h}$. Post-incubation, Cr-SPs were removed, cells were washed with fresh media, and then the cells were incubated with fresh medium at $37{ }^{\circ} \mathrm{C}$ for $24 \mathrm{~h}$. Post $24 \mathrm{~h}$, MTT assay was performed to check the bacterial cell viability as described above [43].

\section{Antibiofilm Potential of Cr-SPs}

Antibiofilm potential of a bioactive compound can be assessed by checking for its inhibitory potential, i.e. preventing the formation of the biofilm as well as eradication potential, i.e. disruption of preformed biofilms at a target site.

\section{Biofilm Inhibition Assay}

The ability of Cr-SPs in inhibiting biofilm formation was determined using the modified microtiter plate method. The overnight grown bacterial culture was further inoculated in a fresh GM3 medium till it reaches to 0.5 O.D. Approximately $100 \mu \mathrm{L}$ of this culture was treated with $0.5-8 \mathrm{mg} / \mathrm{mL}$ concentrations of Cr-SPs, incubated at $37{ }^{\circ} \mathrm{C}$ for $24 \mathrm{~h}$. After incubation, the planktonic cells were removed, and the biofilms were washed with sterile distilled water, stained with $1 \%$ crystal violet $(\mathrm{CV})$ and incubated at room temperature for $30 \mathrm{~min}$. Later, the stained biofilms were washed with sterile distilled water twice, the contents in the wells were dried, and CV bound cells were solubilised with $100 \%$ ethanol and were quantified spectrophotometrically at $595 \mathrm{~nm}$ [42]. The data was analysed by plotting the Cr-SPs concentration on $\mathrm{X}$-axis vs percent biofilm inhibition on Y-axis.

\section{Cell Surface Hydrophobicity Assay (CSH)}

Hydrophobic nature of the bacterial cell surface is one of the important factors for bacterial adherence on biotic and abiotic surfaces, biofilm initiation and colonization [44]. Cell surface hydrophobicity (CSH) was determined using bacterial adherence to hydrocarbons assay. For this experiment 0.6 O. D measuring overnight grown culture were taken, cells were harvested and suspended in fresh medium containing MIC and double minimum inhibitory concentration (D-MIC) of Cr-SPs and incubated further for $24 \mathrm{~h}$ at $37{ }^{\circ} \mathrm{C}$ at 
$120 \mathrm{rpm}$. Post-incubation, bacterial cell density was measured at $600 \mathrm{~nm}$. Then an equal amount of toluene was added, vortexed for $2 \mathrm{~min}$ and is allowed to separate into phases. The O.D. of the aqueous phase is then recorded at $600 \mathrm{~nm}$. The pre and post recorded absorbance is used for determination of $\mathrm{CSH}[45,46]$.

\section{Biofilm Eradication Assay}

To test the potential of Cr-SPs to distort preformed biofilms using modified microtiter plate $\mathrm{CV}$ assay. Overnight grown bacterial culture was inoculated in a fresh GM-3 medium and incubated till the O.D. reaches to 0.5. The cells were allowed to form biofilm by treating them with $15-\mathrm{mm}$ hydrogen peroxide for $24 \mathrm{~h}$ at $37{ }^{\circ} \mathrm{C}$ at $120 \mathrm{rpm}$. The preformed biofilms were further incubated another $24 \mathrm{~h}$ with $0.5-8 \mathrm{mg} / \mathrm{ml}$ concentrations of Cr-SPs at $37{ }^{\circ} \mathrm{C}$ in shaker conditions $(120 \mathrm{rpm})$. Appropriate blanks and controls were maintained. After incubation at $37{ }^{\circ} \mathrm{C}$ for $24 \mathrm{~h}$, the cells were stained with $\mathrm{CV}$ and processed as discussed above. The CV bound biofilms were solubilised by adding $100 \%$ ethanol and measured at $595 \mathrm{~nm}[44,47]$.

\section{Extracellular Polysaccharide Layer (EPS) Quantification}

Preformed biofilms were treated with different concentrations of Cr-SPs for $24 \mathrm{~h}$ at $120 \mathrm{rpm}, 37{ }^{\circ} \mathrm{C}$ along with proper controls. After $24 \mathrm{~h}$ of incubation, to the suspension $10 \%$ trichloroacetic acid (TCA) and an equal volume of acetone were added and incubated overnight at $4{ }^{\circ} \mathrm{C}$. Post-incubation the reaction mixture was pelleted by centrifuging at $10,000 \mathrm{rpm}$ for $10 \mathrm{~min}$ at $25^{\circ} \mathrm{C}$. Then the weight of Cr-SPs treated pellet was compared to the control and used for quantification of EPS [48].

\section{Extracellular DNA (eDNA) Quantification}

Quantification of extracellular DNA of EPS layer was carried out from preformed biofilms using Wang et al.'s method. [49]. Preformed biofilms were kept at $4{ }^{\circ} \mathrm{C}$ for $1 \mathrm{~h}$, and then 1 $\mu \mathrm{L}$ of $0.5 \mathrm{M}$ EDTA was added and centrifuged at $5000 \mathrm{rpm}$ for $5 \mathrm{~min}$ to remove planktonic cells. The biofilms were then resuspended with $50 \mathrm{mM}$ Tris- $\mathrm{HCl}(\mathrm{pH}$ 8). eDNA from these biofilms was extracted with an equal volume of phenol/chloroform/isoamyl alcohol (PCI) $(25: 24: 1)$ and with chloroform/isoamyl alcohol (CI) (24:1). The mixture is allowed to stand for phase separation. The aqueous phase is then treated with 3 volume of ice-cold $100 \%$ ethanol and $1 / 10^{\text {th }}$ volume of $3 \mathrm{M}$ sodium acetate $(\mathrm{pH}$ 5.2) for precipitation of DNA in each sample and stored at $-20{ }^{\circ} \mathrm{C}$. Next day eDNA was obtained by centrifuging at $18,000 \times \mathrm{g}$ for $20 \mathrm{~min}$ at $4{ }^{\circ} \mathrm{C}$. eDNA was then suspended in $20 \mu \mathrm{L}$ of Tris-EDTA (TE) buffer. The eDNA was quantified by checking the absorbance values at A260/A280 using Tecan Nanodrop 2000.

\section{Anti-quorum Sensing Assays}

\section{Motility Assays: Swimming and Swarming Inhibition}

The effect of Cr-SPs on bacterial motility was assessed by performing swimming and swarming assay of $S$. marcescens. For this experiment, $10^{6} \mathrm{CFU} / \mathrm{mL}$ of overnight grown 
bacterial culture was treated with different concentrations of Cr-SPs and incubated at $37{ }^{\circ} \mathrm{C}$ for $24 \mathrm{~h}$. After Cr-SPs treatment, $10 \mu \mathrm{L}$ of this culture is seeded on $0.35 \%$ and $0.75 \% \mathrm{GM}-3$ agar plates and incubated overnight at $37{ }^{\circ} \mathrm{C}$ for swimming and swarming assay, respectively. Post-incubation bacterial motility was recorded by observing the agar plates visually [50].

\section{Protease Assay}

A modified Folin-Ciocalteau method was adapted to quantify protease enzyme activity in these bacteria. This assay involves using $1 \%$ casein as a substrate. The MIC and D-MIC Cr-SPs treated bacterial cells were centrifuged at $5000 \mathrm{rpm}$ for $5 \mathrm{~min}$, and the supernatant was treated with an equal volume of the substrate. This enzyme-substrate reaction mixture was incubated at room temperature for $10 \mathrm{~min}$, and then the reaction was stopped by adding $0.4 \mathrm{~N}$ tricholoraceticacid and incubated at $40{ }^{\circ} \mathrm{C}$ for another $10 \mathrm{~min}$. The mixture was then centrifuged at $5000 \mathrm{rpm}$ for $5 \mathrm{~min}$. Further, $5 \mathrm{~mL}$ of $0.4 \mathrm{M}$ sodium carbonate, $1 \mathrm{~mL}$ Folin's reagent were added to $1 \mathrm{ml}$ of supernatant and incubated at $40{ }^{\circ} \mathrm{C}$ for $20 \mathrm{~min}$. Postincubation the protease enzyme activity was measured at $680 \mathrm{~nm}$ [51].

\section{Urease Assay}

The urease activity was evaluated using the Nessler's method. Control and Cr-SPs treated bacterial cultures were centrifuged at $5000 \mathrm{rpm}$ for $5 \mathrm{~min}$ at $25^{\circ} \mathrm{C}$. The supernatant was then treated with $2 \%$ urea for $3 \mathrm{~h}$ at $37^{\circ} \mathrm{C}$. To this $0.1 \mathrm{~mL}$ of Nessler's reagent was added and further incubated for $5 \mathrm{~min}$ at room temperature. Urease was quantified spectrophotometrically at $530 \mathrm{~nm}$ [52].

\section{Prodigiosin Pigment Assay}

Interfering with host immune clearance mechanisms, manifesting cytotoxic properties and exhibiting pro-inflammatory properties are some of the ways in which the microbial pigment plays a key role in contributing to disease pathogenesis. Prodigiosin pigment produced by $S$. marcescens was quantified with/without Cr-SPs treatment. Briefly, $200 \mu \mathrm{L}$ of 0.5 O.D bacterial culture was treated with different concentrations of Cr-SPs and incubated at $37{ }^{\circ} \mathrm{C}$ for $24 \mathrm{~h}$. After incubation the cells were centrifuged at $10,000 \mathrm{rpm}$ for $10 \mathrm{~min}$, resuspended in acidified ethanol solution ( $96 \mathrm{ml}$ of ethanol containing $4 \%$ of $1 \mathrm{M} \mathrm{HCl}$ ) for extraction of prodigiosin. The extracted prodigiosin was assayed spectrophotometrically at $534 \mathrm{~nm}[53,54]$.

\section{Scanning Electron Microscopy (SEM) Analysis}

SEM analysis was performed to microscopically visualize and confirm the eradication of bacterial biofilms upon treatment with Cr-SPs. Preformed biofilms on glass coverslips were treated with MIC of Cr-SPs for $24 \mathrm{~h}$ at $37{ }^{\circ} \mathrm{C}$. Proper controls were maintained for each of the organism. After treatment with the Cr-SPs for $24 \mathrm{~h}$, the cells were washed with phosphate-bufferred saline (PBS) thrice and fixed for $12 \mathrm{~h}$ using $2.5 \%$ glutaraldehyde. After fixing, the cells were dehydrated using $50-100 \%$ graded ethanol and subjected to desiccation for $24 \mathrm{~h}$. Platinum was used to coat these biofilms and were visualized using scanning 
electron microscope (FEI Quanta 200 (XT Microscope Control)) at a magnification of $20,000 \times[55]$.

\section{Statistical Analysis}

The data generated from triplicate sets of each experiment was analysed using OriginPro 8.5 tool. Further, one-way analysis of variance (ANOVA) using IBM-SPSS software was done for the comparisons of treated samples to proper controls.

\section{Results}

\section{Extraction and Biochemical Characterization of Cr-SPs}

The sulphated polysaccharides were purified and evaluated for its biochemical composition. The purified extract was found to have $~ 70 \%$ total carbohydrate, $31.32 \%$ sulphate, $40.31 \%$ uronic acid and protein content as low as of $6.19 \%$. FTIR analysis showed an asymmetric $\mathrm{S}=\mathrm{O}$ stretching vibrations $\left(1219.56\right.$ and $\left.1377.01 \mathrm{~cm}^{-1}\right)$ indicating the absorption of characteristic sulphate groups and characteristic bending vibrations of C-O- $\mathrm{SO}_{3}$ $\left(1066.63 \mathrm{~cm}^{-1}\right)$ and C-O-S groups $\left(1158.56 \mathrm{~cm}^{-1}\right)$ and offered comprehensive information about the side chains, and Cr-SPs have shown to have similar characteristics like algal SPs [33]. NMR results showed characteristic $\alpha$-D-galacturonic acid signals at $5.1 \mathrm{ppm}$; chemical shifts from 3.3-3.9 are likely the protons of the glycosidic rings and thus helped in revealing the structural characteristics of Cr-SPs [56]. The extract enriched with Cr-SPs was further used for antibacterial studies.

\section{Agar Well Diffusion Assay}

The agar well diffusion test is used to visualize the anti-microbial properties of Cr-SPs by measuring the diameter of the zones of growth inhibition in the agar plates. It was observed that there was increased diameters of clear zones of bacterial growth inhibition around

Table 1 Effect of Cr-SPs on bacterial growth. Zone diameters observed after Cr-SPs treatment in K. pneumoniae and $S$. marcescens

\begin{tabular}{lll}
\hline Concentration $(\mathrm{mg} / \mathrm{ml})$ & \multicolumn{2}{l}{ Zone of inhibition $(\mathrm{mm})$} \\
\cline { 2 - 3 } & K. pneumonia & S. marcescens \\
\hline 0 & 0 & 0 \\
0.5 & $15 \pm 1.06$ & $14.3 \pm 0.33$ \\
1 & $15.66 \pm 1.41$ & $15.8 \pm 0.67$ \\
2 & $16.76 \pm 0.70$ & $16 \pm 0.33$ \\
4 & $17.25 \pm 1.06$ & $16.3 \pm 0.33$ \\
8 & $18 \pm 1.06$ & $16.6 \pm 0.40$ \\
12 & $19.75 \pm 0.288$ & $16.6 \pm 0.33$ \\
16 & $21.5 \pm 0.35$ & $17.3 \pm 0.47$ \\
32 & $21.5 \pm 0.35$ & $19.17 \pm 0.55$ \\
\hline
\end{tabular}


the wells of both $K$. pneumoniae and S. marcescens with increased Cr-SPs concentration. Table 1 depicts the zone diameters showing the antimicrobial property of Cr-SPs. In case of $K$. pneumoniae, the inhibition zones range in diameter from 0 to $21.5 \mathrm{~mm}$, while in $S$. marcescens it ranges from 0 to $\sim 19.7 \mathrm{~mm}$, respectively. This result indicates that Cr-SPs efficiently inhibited the growth of both the bacteria tested.

\section{Time-Kill and Colony-Forming Unit Assay}

The time and dose-dependent action of Cr-SPs was evaluated by the time-kill curve generated over a period of 0 to $48 \mathrm{~h}$. From the results of time-kill curve depicted in Fig. 1a and $\mathrm{b}$, it was observed that there was a dose- and time-dependent inhibition of the growth of these bacteria at all concentrations up to $4 \mathrm{mg} / \mathrm{mL}$. At $8 \mathrm{mg} / \mathrm{mL}$, Cr-SPs showed a bactericidal effect starting from the first $3 \mathrm{~h}$ of Cr-SPs treatment. In comparison to the control, all concentration of Cr-SPs showed efficient antibacterial activity with a decline in the growth curve with increasing concentration and time.

Colony-forming unit assay results showed that Cr-SPs was effectively inhibited the clonal propagation in both these bacteria. There was gradual decrease in the number of colonies formed by these bacteria with increase in the concentration of Cr-SPs. It was

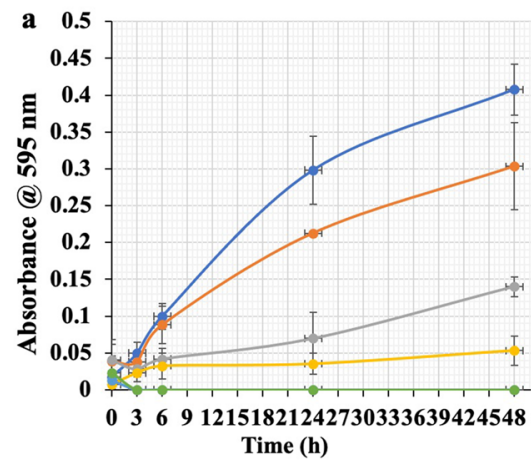

b
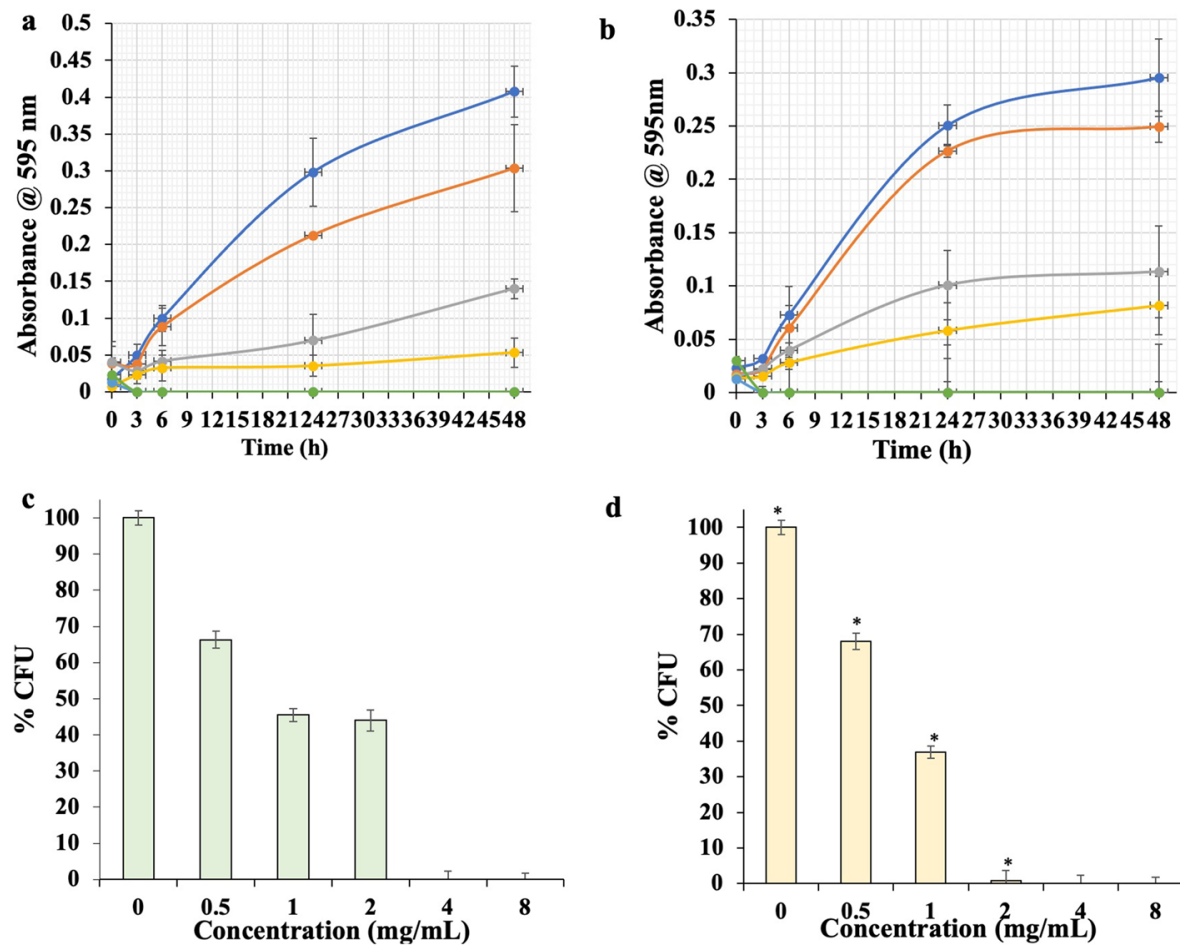

d

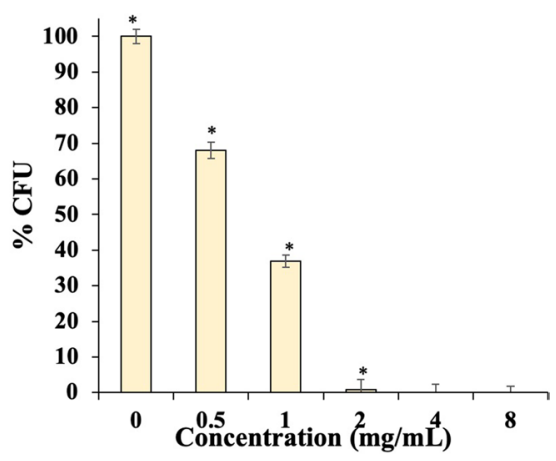

Fig. 1 Time-kill curves of Cr-SPs a K. pneumoniae and b S. marcescens. Different colours indicate different Cr-SPs concentrations. Blue, $0 \mathrm{mg} / \mathrm{mL}$; orange, $0.5 \mathrm{mg} / \mathrm{mL}$; grey, $1 \mathrm{mg} / \mathrm{mL}$; yellow, $2 \mathrm{mg} / \mathrm{mL}$; and green, $4 \mathrm{mg} / \mathrm{mL}$; dark blue, $8 \mathrm{mg} / \mathrm{mL}$. Effect of Cr-SPs on colony-forming units of $\mathbf{c}$ K. pneumoniae and d $S$. marcescens after Cr-SPs treatment. The data obtained are means of three replicates $\pm \mathrm{SE}$. Asterisks indicate significant differences amongst control and Cr-SPs treated samples $(p<0.05)$ 
observed that at $1 \mathrm{mg} / \mathrm{mL}$ of Cr-SPs, more than $50 \%$ reduction in bacterial cells ability to form colonies was seen in both the bacteria (Fig. 1c and d). At 4 and $8 \mathrm{mg} / \mathrm{mL} \mathrm{Cr}$ SPs, no colonies were observed showing a complete inhibition of bacterial clonal propagation indicating the bactericidal potential of Cr-SPs.

\section{MIC and MBC Determination}

MIC and MBC value of Cr-SPs against $K$. pneumoniae and $S$. marcescens was measured using modified MTT assay. Cr-SPs showed a $\mathrm{MIC}_{50}$ of $850 \mu \mathrm{g} / \mathrm{mL}$ in K. pneumoniae, and it was $800 \mu \mathrm{g} / \mathrm{mL}$ for $S$. marcescens, respectively (Fig. 2a and b). In case of $K$. pneumoniae, a complete bacterial growth inhibition was observed at $4 \mathrm{mg} / \mathrm{mL}$ and beyond, while in $S$. marcescens, complete growth inhibition was observed at $8 \mathrm{mg} / \mathrm{mL}$. MBC results of Cr-SPs showed that in both the tested bacteria $50 \%$ bacterial growth inhibition was found at $2 \mathrm{mg} / \mathrm{mL}$, while $8 \mathrm{mg} / \mathrm{mL}$ showed complete growth inhibition indicating that Cr-SPs indeed has indeed bactericidal effect against $K$. pneumoniae and S. marcescens (Fig. 2c and d).
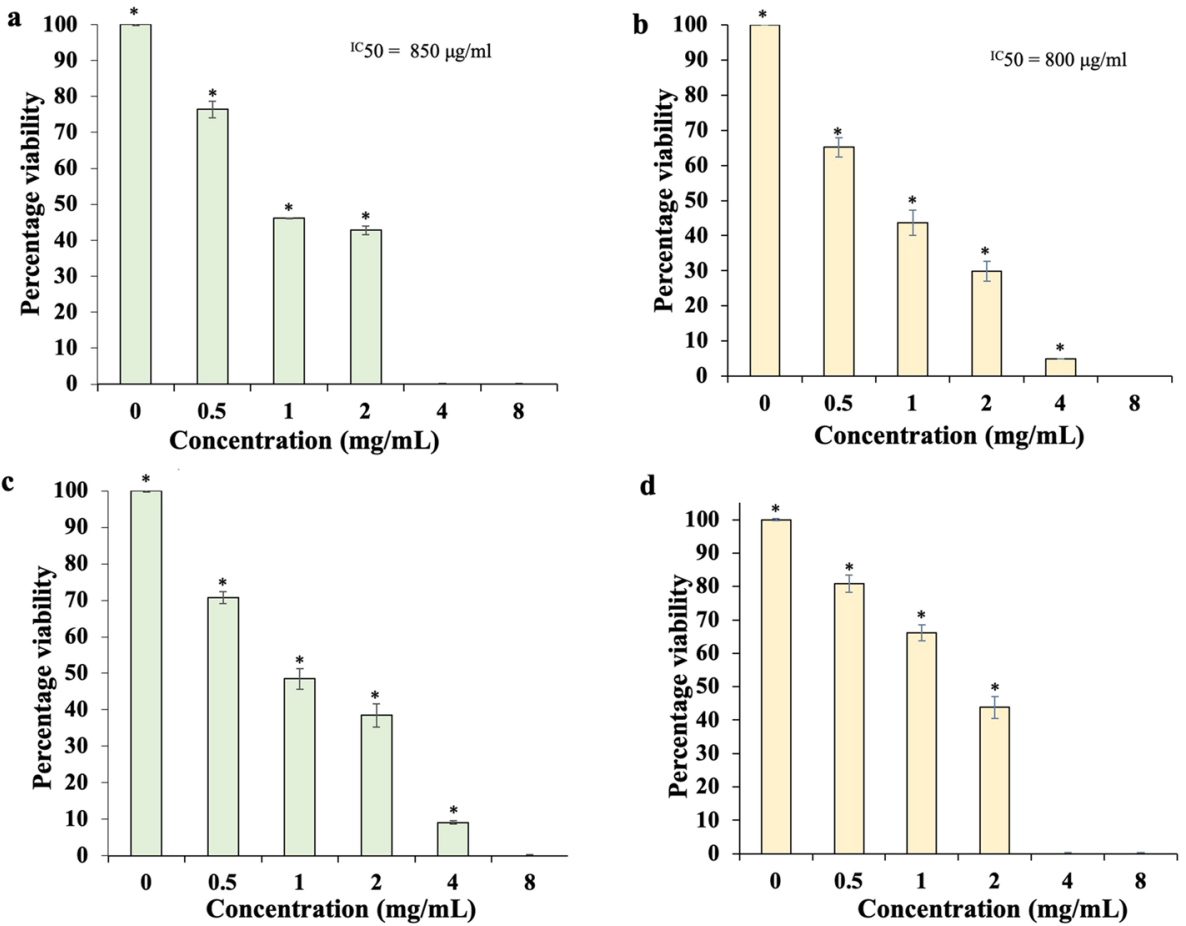

Fig. 2 MIC of Cr-SPs against a $K$. pneumoniae and b $S$. marcescens, MBC of Cr-SPs against c K. pneumoniae and $\mathbf{d} S$. marcescens. The data obtained are means of three replicates $\pm \mathrm{SE}$. Asterisks indicate significant differences amongst control and Cr-SPs treated samples $(p<0.05)$ 


\section{Effect of Cr-SPs to Inhibit Biofilm Formation and Alter Bacterial Cell Surface Hydrophobicity}

Cr-SPs ability to inhibit biofilm formation in $K$. pneumoniae and $S$. marcescens was studied using the CV assay. It was observed that bacterial cells treated with $0.5 \mathrm{mg} / \mathrm{mL}$ of Cr-SPs showed more than $50 \%$ of biofilm formation was inhibited in both the organisms, while complete biofilm inhibition was observed above $4 \mathrm{mg} / \mathrm{mL}$ of Cr-SPs in $K$. pneumoniae and S. marcescens, respectively (Fig. $3 \mathrm{a}$ and b).

To check if Cr-SPs can alter the hydrophobic properties of bacterial cells, cell surface hydrophobicity $(\mathrm{CSH})$ assay was performed. It is known that hydrophobic nature of bacterial cell surface plays an important role in bacterial adherence during biofilm formation and the effect of Cr-SPs on CSH was assessed using BATH assay. It was observed that after treatment with MIC and D-MIC of Cr-SPs, CSH of the bacteria was decreased from $\sim 82 \%$ in control to $\sim 61 \%$ in K. pneumoniae, while it was reduced from $\sim 72$ to $13 \%$ in case of $S$. marcescens, respectively (Fig. $3 c$ and d). These results clearly indicate that Cr-SPs probably altering the hydrophobic nature of these bacteria, thereby inhibiting them to adhere onto a surface and inhibiting biofilm formation.
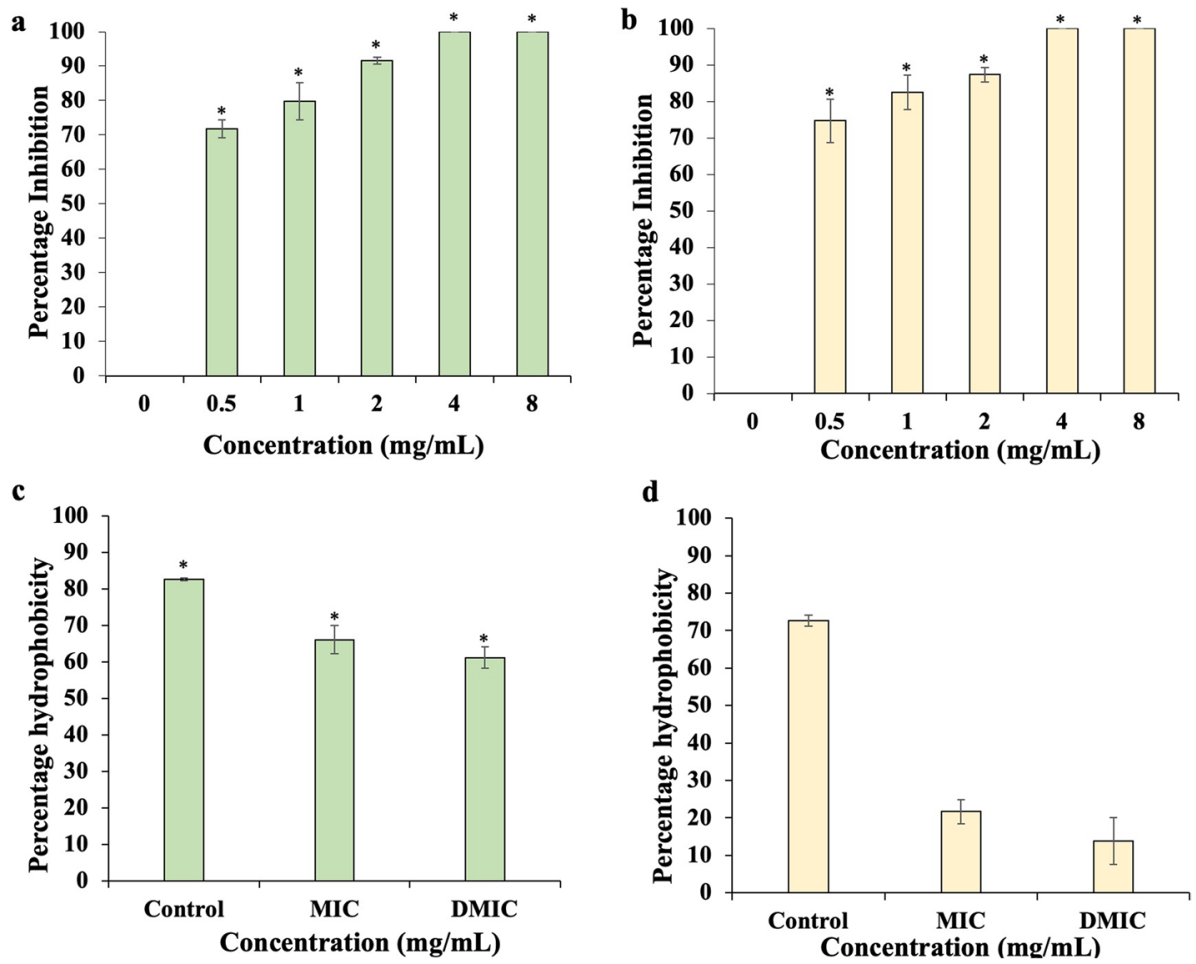

Fig. 3 Inhibition of bacterial biofilm formation by Cr-SPs in a $K$. pneumoniae and $\mathbf{b} S$. marcescens. Cr-SPs reduce bacterial cell surface hydrophobicity in $\mathbf{c} K$. pneumoniae and $\mathbf{d} S$. marcescens. The data obtained are means of three replicates \pm SE. Asterisks indicate significant differences amongst control and Cr-SPs treated samples $(p<0.05)$ 


\section{Effect of Cr-SPs in Eradicating Preformed Biofilms and Extra Polymeric Substance (EPS) Quantification Assay}

In order to check if Cr-SPs can disrupt preformed-biofilms of $K$. pneumoniae and $S$. marcescens, biofilm eradication assay was performed. From the results it can be observed that there was positive correlation with concentration of Cr-SPs and increased percent eradication of preformed-biofilm in these bacteria. More than $50 \%$ of preformed bacterial biofilm was eradicated at $0.5 \mathrm{mg} / \mathrm{mL}$ of Cr-SPs treatment, while $100 \%$ biofilm eradication is seen at $4 \mathrm{mg} / \mathrm{mL}$ and $8 \mathrm{mg} / \mathrm{mL}$, respectively (Fig. $4 \mathrm{a}, \mathrm{b}$ ).

The EPS quantification also helped us to determine the biofilm eradication ability of Cr-SPs. The results clearly indicated reduction in total EPS quantity when compared to control. The results showed that there was a ten-fold reduction in EPS in case of $K$. pneumoniae (Fig. 4c), while in case of $S$. marcescens, the reduction was up to three-fold as compared to control (Fig. 4d), indicating that Cr-SPs efficiently disrupted the protective matrix of the mature biofilm thereby distorted the biofilm.
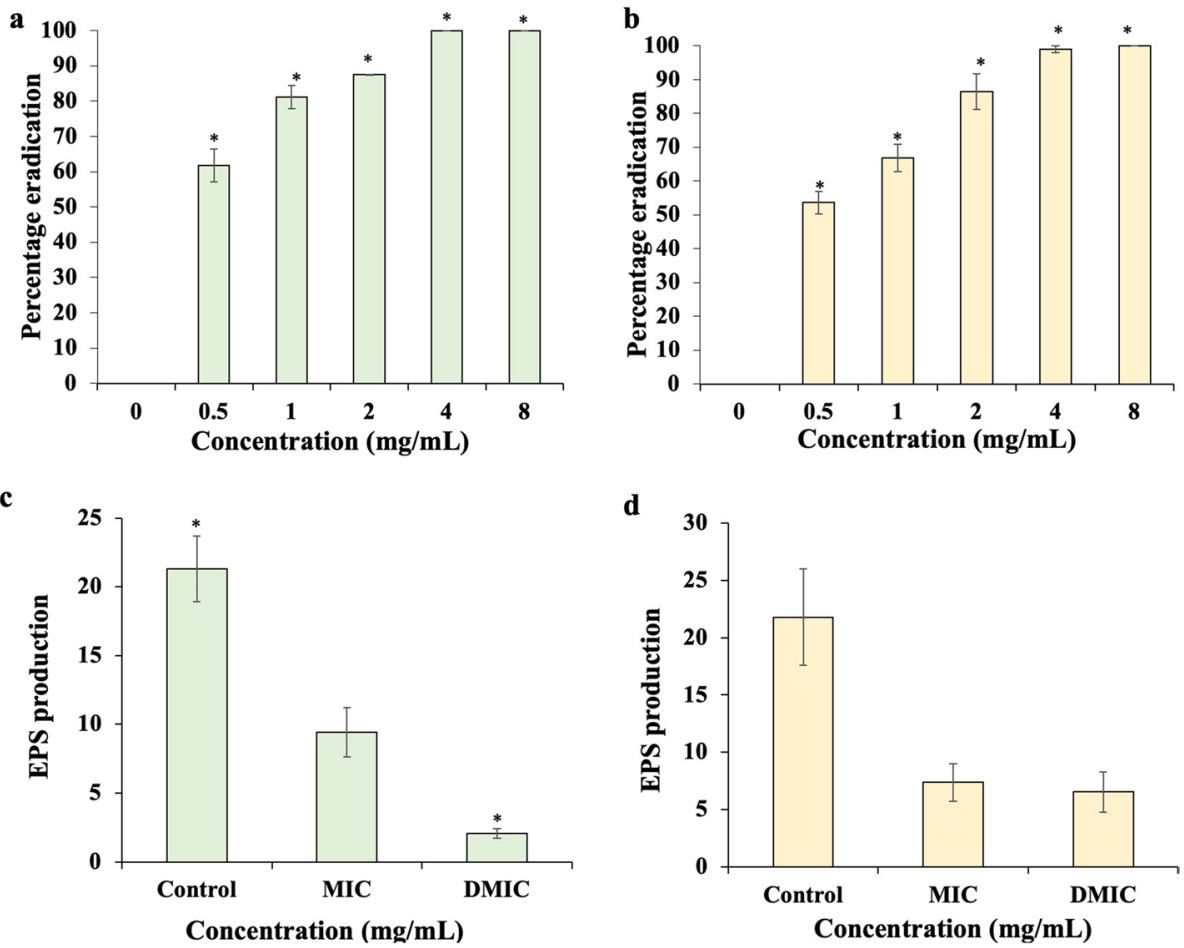

Fig. 4 Effect of Cr-SPs against preformed biofilms of a K. pneumoniae and b S. marcescens. Quantification of EPS with/without Cr-SPs treatment in c $K$. pneumoniae and d S. marcescens. The data obtained are means of three replicates \pm SE. Asterisks indicate significant differences amongst control and Cr-SPs treated samples $(p<0.05)$ 


\section{eDNA Quantification}

eDNA of the EPS layer plays a crucial role in its maintenance and maturation. Quantification of eDNA content of EPS layer helps to understand the potential of Cr-SPs in distorting the EPS layer of the preformed biofilm. The results were evident that with increased concentration of Cr-SPs, there was a drastic reduction in the eDNA content of the treated cells. In case of $K$. pneumoniae, as compared to control, $4 \mathrm{mg} / \mathrm{mL} \mathrm{Cr-SPs}$ treated cells showed 20-fold decrease in the eDNA content (Fig. 5a). Similarly, in S. marcescens $8 \mathrm{mg} / \mathrm{mL}$ concentration of Cr-SPs showed $\sim 17$-fold reduction in eDNA content (Fig. $5 \mathrm{~b}$ ). These results indicate that Cr-SPs not only inhibited the adhesion of bacteria on to a surface but also distorted the preformed bacterial biofilms probably targeting the EPS layer components.

\section{Motility Assay}

The swimming and swarming motility help the bacteria cells to adhere on biotic and abiotic surfaces as well as for dispersal from the biofilm. It is known that bacterial quorum sensing communication mechanism helps in regulating this flagellar motilities. In S. marcescens it was observed that MIC of Cr-SPs treated cells showed reduced swimming and swarming motility, while D-MIC of Cr-SPs showed a complete restriction in bacterial movement as compared to untreated controls (Fig. 6a and b). This result indicates that Cr-SPs probably targeting the quorum sensing pathway in this bacteria, thereby inhibiting the biofilm formation and transmitting the bacterial infections.

\section{Effect of Cr-SPs on Virulence Factors}

Quorum sensing mechanism is known to activate genes that are responsible for virulence factors. Enzyme like proteases, ureases and lipases play an important role in disease
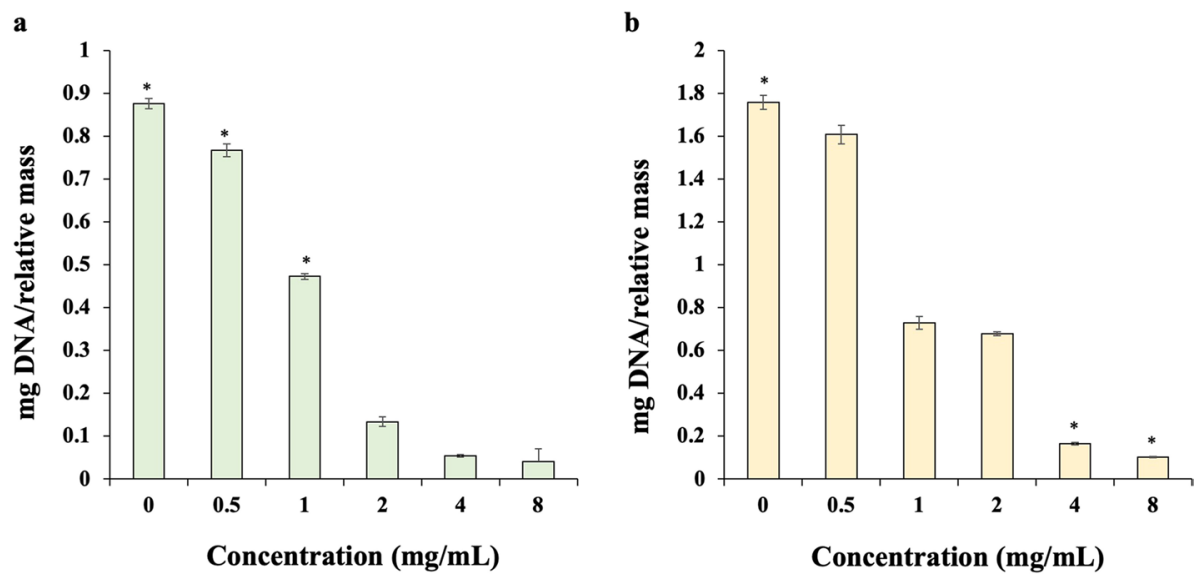

Fig. 5 extracellular DNA Quantification with/without Cr-SPs-treated preformed biofilms of a K. pneumoniae and $\mathbf{b} S$. marcescens. The data obtained are means of three replicates $\pm \mathrm{SE}$. Asterisks indicate significant differences amongst control and Cr-SPs treated samples $(p<0.05)$ 
$\mathbf{A}$
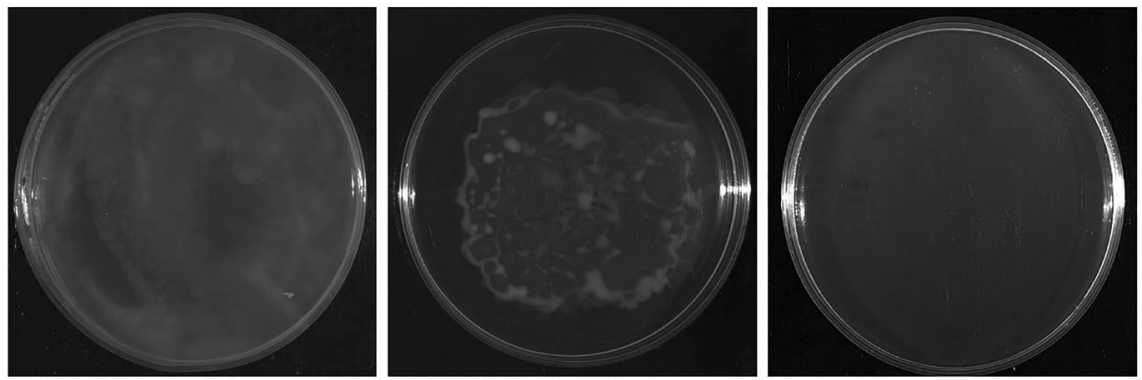

B
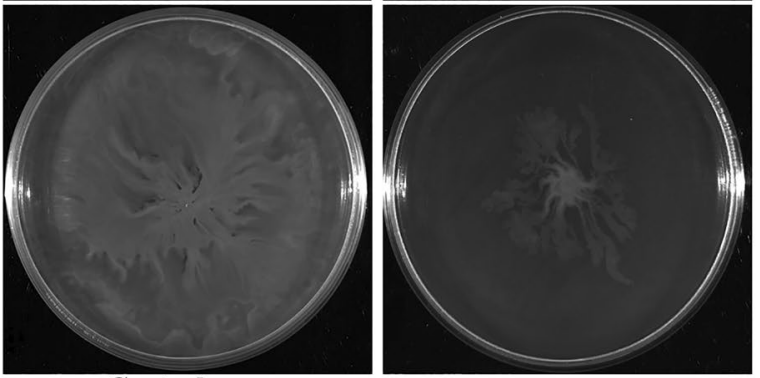

MIC

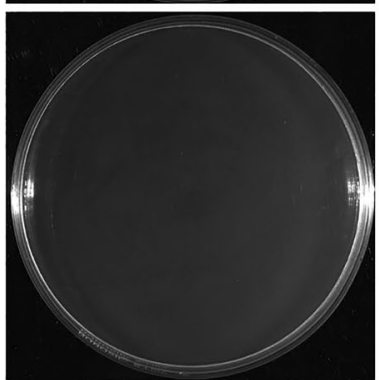

D-MIC

Fig. 6 Cr-SPs effect on a bacterial swimming motility and $\mathbf{b}$ bacterial swarming motility of $S$. marcescens

propagation. Proteases help in degrading immunoglobulins, while ureases help to protect bacterial cells from acidic environments. Hence, a potential anti-quorum sensing agent should affect the production of these QS role players. In the current study, it was observed that in K. pneumoniae the cells when treated with MIC of Cr-SPs showed $30 \%$ reduced protease activity, while D-MIC of Cr-SPs showed $\sim 35 \%$ reduced protease activity as compared to control (Fig. 7a), while in $S$. marcescens showed $\sim 42 \%$ and $\sim 49 \%$ reduced activity protease activity with MIC and DMIC of Cr-SPs, respectively (Fig. 7b).

In case of urease production, it was observed that in $K$. pneumoniae the cells when treated with MIC and D-MIC of Cr-SPs showed $73 \%$ and $93 \%$ reduced activity as compared to untreated controls (Fig. 7c), while in S. marcescens MIC and D-MIC of Cr-SPs showed $63 \%$ and $70 \%$ reduced activity (Fig. 7d). These results clearly indicate that Cr-SPs interfered the QS pathway and effectively reduced the activities of virulence factors associated with disease progression.

\section{Pigment Assay}

S. marcescens is known to produce prodigiosin pigment under the control of QS mechanism. This pigment is known to hamper host immune system and is cytotoxic to host cell. Prodigiosin is required for the bacteria for its survival and pathogenicity [43, 44]. The result showed that there is a positive correlation with concentration of Cr-SPs and reduced prodigiosin pigment production of $S$. marcescens. The pigment production is reduced significantly to $52 \%$ and $80 \%$ when treated with MIC and D-MIC of Cr-SPs, respectively (Fig. 7e). This pigment inhibition assay results indicate that Cr-SPs has promising potential in interfering the QS mechanism and its associated pathogenicity. 

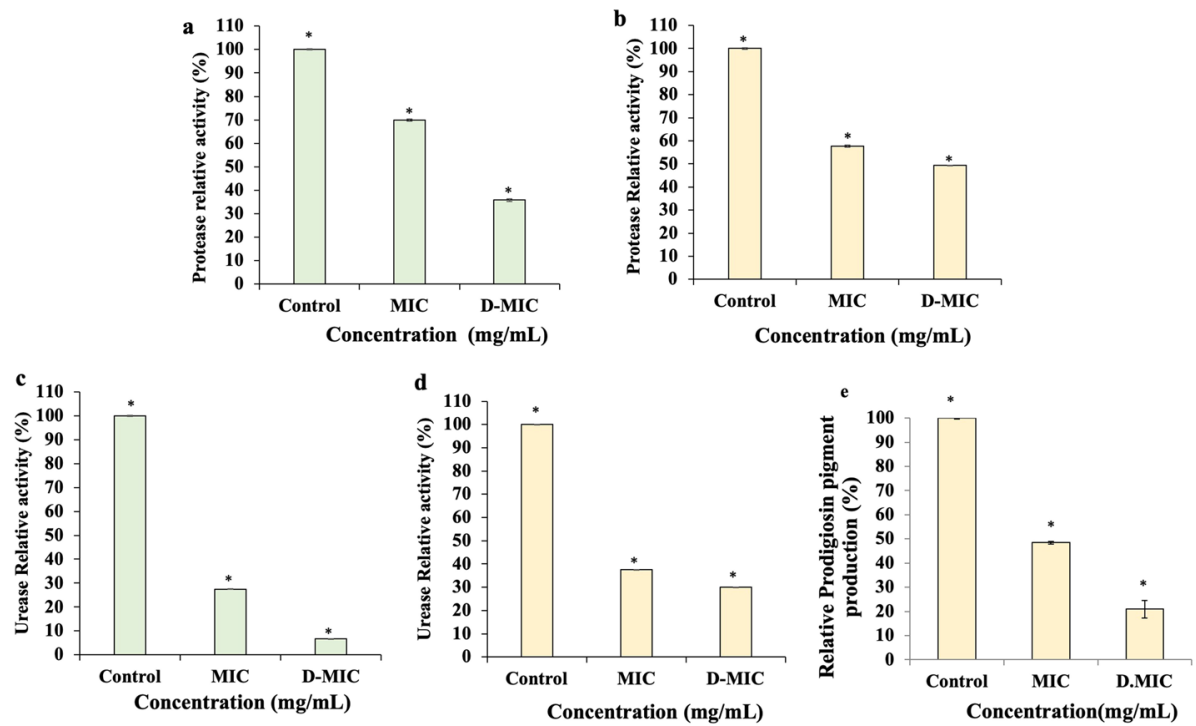

Fig.7 Quorum sensing inhibition potential of Cr-SPs. Protease activity in a K. pneumoniae and b $S$. marcescens after Cr-SPs treatment. Urease activity analysis in $\mathbf{c} K$. pneumoniae and $\mathbf{d} S$. marcescens post Cr-SPs treatment. e The effect of Cr-SPs on prodigiosin pigment production of $S$. marcescens. The data obtained are means of three replicates \pm SE. Asterisks indicate significant differences amongst control and Cr-SPs treated samples $(p<0.05)$

\section{SEM Analysis}

SEM analysis was done to visually observe the biofilm disruption after Cr-SPs treatment. There was a drastic decrease in the number of adherent bacteria in the Cr-SPs treated biofilm culture as compared to control. A clear disruption of biofilm was observed. SEM analysis also showed a drastic morphological change amongst the bacterial cells in the Cr-SPs treated culture (Fig. 8). These findings suggest that Cr-SPs is a potential antibiofilm agent which distort the mature biofilms and also prevents further disease progression of these respiratory infection causing bacteria.

\section{Discussion}

Respiratory diseases are life threatening, and hence their prevention, control and cure have to be a top priority. About 65 million people suffer from COPD of which nearly 3 million die each year making COPD an important cause of death worldwide $[2,57]$. Lower respiratory tract disorder causes death of $\sim 4$ million people a year especially among children under 5 years of age [49]. Tuberculosis (TB) a type of severe respiratory tract infection leads to 1.4 million deaths in the year 2015 while lung cancer kills around 1.6 million people each year $[58,59]$. It is estimated that 334 million people suffer from asthma including children. Around 9 million children under the age of 5 years die each year due to pneumonia [60-63]. A major causative agent of RTIs are pathogenic bacteria and their biofilm forming ability. Bacterial cells exhibit two types of growth modes, i.e. planktonic mode and biofilm mode. Biofilm is an association of microorganisms where cells adhere to one 

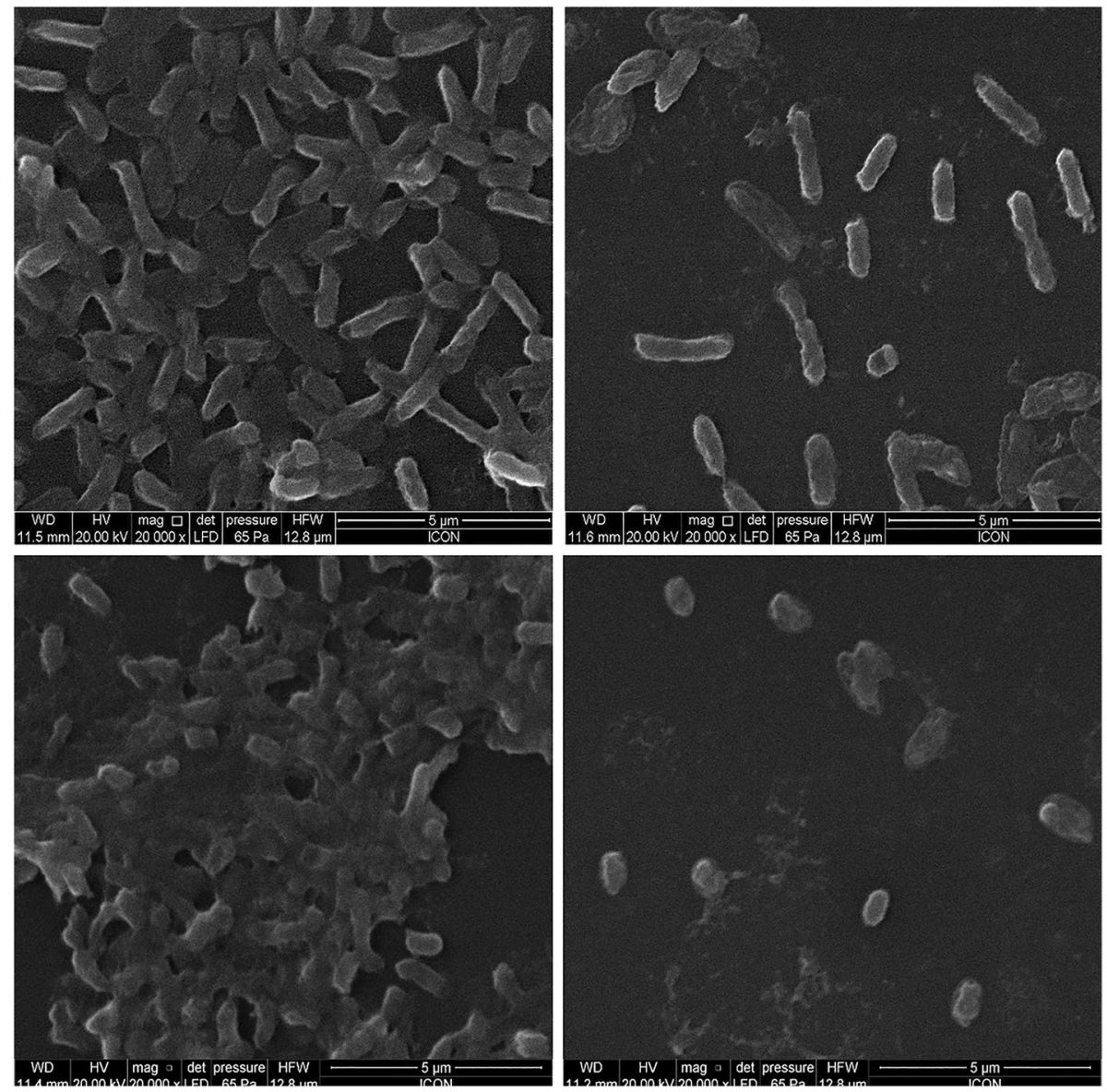

Fig. 8 Scanning electron micrographs of a $K$. pneumoniae control and c S. marcescens control and Cr-SPs treated b K. pneumoniae and d $S$. marcescens biofilms. Magnification $\times 20,000$; bars $=5 \mu \mathrm{M}$

another on a surface which is encased within a protective matrix [64, 65]. Bacterial biofilm is usually pathogenic in nature and causes nosocomial infections [65]. Quorum sensing is the primary bacterial communication mechanism during biofilm formation. Small chemical signals are released into the environment by these bacteria, which are perceived by the receptors present on the bacterial surface, thereby initiating a series of gene expression inducing virulence, biofilm formation and bioluminescence. Bacterial biofilm is less accessible to antibiotics and human immune system, thereby posing a significant threat to public health given its involvement in a wide range of infectious diseases [66].

Algae have known to produce many bioactive compounds, but attention has been recently drawn to sulphated polysaccharides due to their potential medicinal activities such as antioxidant, anticoagulant, immunomodulatory and antitumor. Many bioactive compounds from algae are studied for antimicrobial, antioxidant properties. The green marine micro-algae Dunaliella salina showed antimicrobial properties against an array of organisms namely E. coli, P. aeruginosa, and S. aureus showed the same properties [67]. 
In the present study, Cr-SPs from green algae was extracted, purified and structurally characterized both by FTIR and NMR analysis $[33,56]$. The biochemical composition of the extract found to be enriched with polysaccharides $(\sim 70 \%)$, uronic acid $(40.31 \%)$ and sulphate $(31.32 \%)$. Earlier, studies showed that acetone and aqueous extraction are also most prevalent method in SPs production from seaweeds, but short extraction time, noncorrosive solvent and cost-effective environment techniques are required for high yield [68, 69]. This Cr-SPs enriched extract was then tested for its antibacterial and antibiofilm activities subsequently.

The antibacterial activity of Cr-SPs was confirmed by various invitro assays, and the results shows that it has inhibitory as well as bactericidal activity against these respiratory infection causing bacteria. Cr-SPs showed low $\mathrm{MIC}_{50}$ values of $800 \mu \mathrm{g} / \mathrm{mL}$ and $850 \mu \mathrm{g} / \mathrm{mL}$ (Fig. 2). There are not many reports that addressed the antibacterial activity of SPs from fresh water microalgae; however there are some studies with SPs extracted from marine algae. Earlier studies showed that fucoidan from marine algae exerted antimicrobial activity against Streptococcus spp. Similarly, other report showed that brown algal fucoidan has broad antibacterial spectrum against various bacteria like E. coli, P. aeruginosa, K. pneumoniae, and V. cholera. In another reported it has been identified that carrageenan a red algal SPs showed bactericidal activity at $2.5 \mathrm{mg} / \mathrm{mL}$ against $S$. enteritidis, S. typhimurium, E. coli, and $S$. aureus. However, there was no antibacterial activity even at $5000 \mu \mathrm{g} / \mathrm{mL}$ was observed in case of $\Upsilon$-carrageenans [68]. The polysaccharides and sulphated polysaccharides obtained from algal species are known to exhibit antibacterial properties for the reason that they show glycoprotein receptors present on their surface which specifically binds to bacterial cell wall components, the nucleic acid groups and the cytoplasmic membrane and kill them [69]. SPs such as laminarin and fucoidan inhibited the growth of $S$. aureus, Escherichia coli and also biofilms caused by Helicobacter pylori [70].

Time-kill assay showed decreased bacterial growth as the concentration of Cr-SPs increase from 0.5 to $32 \mathrm{mg} / \mathrm{mL}$ over time. CFU assay showed the potential of Cr-SPs to inhibit clonal expansion of the bacterial cells as indicated by reduced number of colonies formed by $K$. pneumoniae and $S$. marcescens post Cr-SPs treatment in a dose-dependent manner (Fig. 1). It has been noticed that the antibacterial potential of bioactive compounds from plants and algae is mainly because of their ability to permeabilise the bacterial cell membrane, causing the opening of the membrane pores, leading to leakage of intracellular macromolecules such as DNA and proteins resulting in cell death. Both sulphate group and the molecular weight of SPs have been shown to play a significant role in antimicrobial activity [68].

Biofilm mode of bacterial growth is a type of bacterial tolerance mechanism to various exogenous stresses, host immune response, rendering the treatment of biofilms with antimicrobials ineffective. Biofilm formation is therefore a serious threat in many fields, ranging from food industry, biofouling and industrial corrosion to chronic and nosocomial infections [68]. In the current study, Cr-SPs efficiently inhibited biofilm formation. It was observed that there was significantly reduced biofilm formation in both the bacteria tested with increased Cr-SPs concentration (Fig. 3). Furthermore, CSH results showed that cells treated with Cr-SPs altered the cell surface hydrophobic properties in these bacteria, thereby preventing them to adhere on to a surface (Fig. 3c and d). Earlier reports showed that Funoran, a SPs extracted from the seaweed Gloiopeltis furcata, inhibited binding of various bacteria like S. mutans, Actinomyces sp., Fusobacterium nucleatum, Streptococcus sobrinus and $P$. gingivalis to saliva-coated hydroxyapatite in vitro and also prevented colonization of Streptococcus cricetus and S. sobrinus in rats [71]. It was also reported earlier that two marine microalgae $L$. danicus and L. aporus showed anti-biofilm activity 
against Staphylococcus epidermidis [68]. SPs extracted from C. reinhardtii also showed concentration-dependent increase in the percentage inhibition of biofilm formation against food-borne infections causing bacteria [72]. The probable mode of action of these polysaccharides could be their ability to modify the physical characteristics of bacterial cells, thereby inhibiting them to bind to surfaces, or they might modify the gene expression of recipient bacteria by acting as signalling molecules, or they can also have competitive inhibition of carbohydrate-protein interactions with the bacterial surface, thereby altering the stability of EPS layer [71, 73-76]. However the exact mode of action of Cr-SPs needs to be explored in future.

eDNA is known to play a crucial role in stabilising and maintenance of early and mature biofilm. In case of Pseudomonas biofilms, eDNA helps in stabilising the biofilm. A study demonstrated that if cells were treated with DNAase, it helps in disruption of biofilms at early stages of biofilm formation. However, the same activity was not observed at mature stages. Another similar study showed that eDNA helps in crosslinking with beta toxins in $S$. aureus which helps in formation of EPS matrix [77]. Dose-dependent reduction in eDNA content in the EPS layer revealed that Cr-SPs distort the EPS matrix and destroy the biofilms (Fig. 5). Furthermore, SEM has been known to be an effective technique to observe the effect of antibiofilm agents on bacterial biofilm formation and eradication. SEM has the ability to observe the morphology of biofilm bacteria and their spatial organisation because of its high-throughput magnification and resolution abilities [78]. In the current study, the SEM results clearly showed that Cr-SPs not only distorted the mature biofilm but also altered the morphology of these bacteria, thereby enabling the bacteria to die even after dispersal (Fig. 8). As reported earlier the common morphological change observed in Gram-negative bacteria post antibiotic treatment is their unusual elongation in bacterial cells due to specific binding of $\beta$-lactams to cellular surface protein components responsible for septum formation and separation of dividing organisms [79-81]. Therefore Cr-SPs can be a promising agent for biofilm disintegration and treatment of the disease.

Multiple studies have shown that during the time of biofilm formation and dispersal, the pathogens can communicate with each other using a phenomenon known as quorum sensing. A growing interest in inhibition of quorum sensing (QS) especially is seen with increased incidence of drug failure. This is majorly due to the pathogenic bacteria developing resistance to large array of antibiotics. Therefore, targeting pathogenesis may help in decreased emergence of resistant strains. Competitive inhibition, degradation of signalling molecules and their receptors and inhibition of genetic regulation systems are various ways in which QS can be targeted [82-84]. Many clinically associated bacteria use QS for the regulation of the collective production of virulence factors. Many genes are controlled by the QS mechanism which is directly involved in many activities like bioluminescence, competence, virulence, antibiotic production and biofilm formation [85]. Swimming, swarming and twitching motilities observed in various strains help in adherence of bacteria and subsequently in the formation of biofilm. The impairment of bacterial motility was also a potential target to inhibit communication [86-89]. In this study it was observed that Cr-SPs effectively inhibited virulence factor production like protease and urease enzyme activities (Fig. 7) and also affecting the motility of these causing bacteria (Fig. 6). Cr-SPs treated $S$. marcescens cells showed significant decrease in the pigment prodigiosin production indicating that they are probably interfering the quorum sensing mechanism and reducing their pathogenicity (Fig. 7e). Earlier reports with curcumin also showed decreased prodigiosin pigment production with increased curcumin concentrations in S. marcescens [14]. 


\section{Conclusion}

The current work clearly shows that Cr-SPs is a promising antibiofilm agent that can both prevent and eradicate RTI bacterial biofilms. The results also indicate that the Cr-SPs is likely interfering the quorum sensing pathway and inhibiting biofilm formation and disease progression. Cr-SPS effectively eradicated preformed biofilms by degrading the eDNA of the EPS matrix. With further screening and validation, these Cr-SPs can be developed as novel antibiofilm agents against respiratory infections causing superbugs.

Author contribution VLS: idea and concept of the work, data analysis and manuscript editing, JSV: performed and validated all experiments, analysed data and drafted the manuscript, BW: performed antibacterial assays like Kirby-Bauer agar diffusion assay, growth kill assay, biofilm inhibition and eradication assays, $\mathrm{BF}$ : performed protease and urease assay and did statistical analysis.

Funding The current study was supported by Department of Atomic Energy, India.

Data availability Available on personal request to corresponding author.

Code Availability Not applicable.

\section{Declarations}

Ethics Approval Not applicable.

Consent to Participate Not applicable.

Consent for Publication All authors approve the manuscript for publication.

Conflict of Interest The authors declare no competing interets.

\section{References}

1. DALYs, G. B. D., \& Collaborators, H. A. L. E. (2015). Global, regional, and national disabilityadjusted life-years (DALYs) for 315 diseases and injuries and healthy life expectancy (HALE), 19902015: A systematic analysis for the Global Burden of Disease Study. Lancet, 388, 1603-1658.

2. World Health Organization. (2007). Global surveillance, prevention and control of chronic respiratory diseases. A comprehensive approach. Geneva, WHO. Available from: http://www.who.int/gard/publi cations/GARD_Manual/en/

3. David, V. B., \& Hansen-Flaschen, J. (2019). Respiratory disease. Encyclopaedia Britannica. inc. https://www.britannica.com/science/respiratory-disease

4. Ahmed Khan, H., Fatima, B. K., \& Riffat, M. (2017). Nosocomila infection: Epidemiology, prevention, control and surveillance. Asia Pacific Journal of Tropical Biomedicine, 7, 478-482.

5. Ducel, G., Fabry, J., \& Nicolle, L. (2000). Prevention of hospital-acquired infections. World health organization, WHO/CDS/CSR/EPH/2002.12.

6. Piperaki, E. T., Syrogiannopoulos, G. A., Tzouvelekis, L. S., \& Daikos, G. L. (2017). Klebsiella pneumoniae. Pediatric. Infectious Disease Journal, 36, 1002-1005.

7. Teanpaisan, R., Kawsud, P., Pahumunto, N., \& Puripattanavong, J. (2017). Screening for antibacterial and antibiofilm activity in Thai medicinal plant extracts against oral microorganisms. Journal of Traditional and Complementary Medicine, 7, 172-177.

8. Wu, M., \& Li, X. (2015). Klebsiella pneumoniae and Pseudomonas aeruginosa. Molecualr Medicine and Microbiology, 3, 1547-1564.

9. Paula-Ramos, L., da Rocha Santos, C. E., Reis Mello, D. C., Theodoro, L. N., De Oliveria, F. E., Brito, G. N. B., Junqueira, J. C., Jorge, A. O. C., \& de Oliveria, L. D. (2006). Klebsiella Pneumoniae 
planktonic and biofilm reduction by different plant extracts: In vitro study. The Scientific World Journal, 2016, 3521413.

10. Hejazi, A., \& Falkiner, F. R. (1997). Serratiamarcescens. Journal of Medicinal Microbiology, 46, 903-912.

11. Mills, J., \& Drew, D. (1976). Serratiamarcescens endocarditis: A regional illness associated with intravenous drug abuse. Annals of Internal Medicine,84, 29-35.

12. Młynarczyk, A., Młynarczyk, G., Pupek, J., Bilewska, A., Kawecki, D., Łuczak, M., Gozdowska, J., Durlik, M., Paczek, L., Chmura, A., \& Rowińnski, W. (2007). Serratiamarcescens isolated in 2005 from clinical specimens from patients with diminished immunity. Transplant Proceed,39, 2879-2882.

13. Stock, I., Burak, S., Sherwood, K. J., Gruger, T., \& Wiedemann, B. (2003). Natural antimicrobial susceptibilities of strains of 'unusual' Serratia species: S. ficaria, S. fonticola, S. odorifera, S. plymuthica and S. rubidaea. Journal of Antimicrobial Chemotherapy, 51, 865-885.

14. Packiavathy, I. A. S. V., Pandian, S. K., Priya, S., \& Ravi, A. V. (2011). Inhibition of biofilm development of uropathogens by curcumin - an anti-quorum sensing agent from Curcuma longa. Food Chemistry, 148, 453-460.

15. Lahiri, D., Nag, M., Dutta, B., Mukherjee, I., Ghosh, S., Dey, A., Banerjee, R., \& Ray, R. R. (2021). Catechin as the most efficient bioactive compound from Azadirachta indica with antibiofilm and antiquorum sensing activities against dental biofilm: An in vitro and in silico study. Applied Biochemistry and Biotechnology,https://doi.org/10.1007/s12010-021-03511-1

16. Memarini, H., Memarini, M., \& Ghasemian, A. (2019). An overview on anti-biofilm properties of quercetin against bacterial pathogens. World Journal of Microbiology and Biotechnology,35, 143.

17. Di Marco, I. N., Paez, L. P., Lucero-Estrada, S. M. C., \& Pungitore, R. C. (2021). Naphthoquinones inhibit formation and viability of Yersinia enterocolitica biofilm. World Journal of Microbiology and Biotechnology,37, 30. https://doi.org/10.1007/s11274-020-02971-7

18. Malheiro, J., Gomes, I., Borges, A., Abreu, A., Mergulhão, F., \& Simões, M. (2014). Phytochemicals efficacy against planktonic bacteria and biofilms. Planta Medica,80, P1L65. https://doi.org/10.1055/s0034-1394722

19. Karthikeyan, A., Rameshkumar, R., Sivakumar, N., Al Amri, I. S., Karutha Pandian, S., \& Ramesh, M. (2012). Antibiofilm activity of Dendrophthoe falcata against different bacterial pathogens. Planta Medica,78(18), 1918-1926. https://doi.org/10.1055/s-0032-1327879

20. Jung, S., Park, O. J., Kim, A. R., Ahn, K. B., Lee, D., Kum, K.-Y., Yun, C.-H., \& Han, S.-H. (2019). Lipoteichoic acids of lactobacilli inhibit Enterococcus faecalis biofilm formation and disrupt the preformed biofilm. Journal of Microbiology, 57, 310-315. https://doi.org/10.1007/s12275-019-8538-4

21. Kim, J. E., Kim, H. E., Hwang, J. K., Lee, H.-J., Kwon, H.-K., \& Kim, B.-I. (2008). Antibacterial characteristics of Curcuma xanthorrhiza extract on Streptococcus mutans biofilm. Journal of Microbiology,46, 228. https://doi.org/10.1007/s12275-007-0167-7

22. Armbruster, C. E.,Mobley, H, L, T., \& Pearson, M. M. (2018). Pathogenesis of Proteus mirabilis infection. EcoSal. Plus, 8https://doi.org/10.1128/ecosalplus.ESP-0009-2017

23. Peter, A., Janat, T., \& Arthur, K. (2017). Nosocomial bacterial infections and their antimicrobial susceptibility patterns among patients in Ugandan intensive care units: A cross sectional study. BMC Research Notes. https://doi.org/10.1186/s13104-017-2695-5

24. Percival, S. L., Suleman, L., Vuotto, C., \& Donelli, G. (2015). Healthcare-associated infections, medical devices and biofilms: Risk, tolerance and control. Journal of Medicinal Microbiology, 64, 323-334.

25. Derek, E. M., \& Bayles, W. K. (2017). Staphylococcus aureus biofilm: A complex developmental organism. Molecualr Microbiology, https://doi.org/10.1111/mmi.13634

26. Ludmylla, C., \& Grenha, A. (2016). Sulfated seaweed polysaccharides as multifunctional materials in drug delivery applications. Marine Drugs, 14, 42. https://doi.org/10.3390/md14030042

27. Jun, J.-Y., Jung, M.-J., Jeong, I.-H., Yamazaki, K., Kawai, Y., \& Kim, B.-M. (2018). Antimicrobial and antibiofilm activities of sulfated polysaccharides from marine algae against dental plaque bacteria. Marine drugs, 16, 301.

28. Wang, L., Wang, X., Wu, H., \& Liu, R. (2014). Overview on biological activities and molecular characteristics of sulfated polysaccharides from marine green. Marine Drugs, 12, 4984-5020.

29. Mungmai, L., Jiranusornkul, S., Peerapornpisal, Y., Sirithunyalug, B., \& Leelapornpisid, P. (2014). Extraction, characterization and biological activities 31. of extracts from freshwater macroalga Rhizoclonium hieroglyphicum (C. Agardh) Kützing] cultivated in Northern Thailand. Chiang Mai Journal of Science, 41, 14-26.

30. Barahona, T., Chandía, N. P., Encinas, M. V., Matsuhiro, B., \& Zúñiga, E. A. (2011). Antioxidant capacity of sulfated polysaccharides from seaweeds.A kinetic approach. Food Hydrocolloidsl,25, $529-535$. 
31. Ma, X. T., Sun, X. Y., Yu, K., Gui, B. S., Gui, Q., \& Ouyang, J. M. (2017). Effect of content of sulfate groups in seaweed polysaccharides on antioxidant activity and repair effect of subcellular organelles in injured HK-2 cells. Oxidative Medicine and Cellular Longevity, 2017, 2542950.

32. Choudhary, S., Save, S., \& Vavilala, L. S. (2018). Unravelling the inhibitory activity of Chlamydomonas reinhardtii sulphated polysaccharides against $\alpha$-synuclein fibrillation. Scientific Reports, 8, 5692.

33. Kamble, P., Sanith, C., Lopus, M., \& Vavilala, S. (2018). Chemical characteristics, antioxidant and anticancer potential of sulfated polysaccharides from Chlamydomonas reinhardtii. Journal of Applied Phycology,30, 1641-1653.

34. Vishwakarma, J., Parmar, V., \& Vavilala, S. L. (2019). Nitrate stress induced bioactive sulfated polysaccharides from Chlamydomonas reinhardtii. Biomedical Research Journal,6, 7-16.

35. Vishwakarma, J., \& Vavilala, S. L. (2019). Evaluating the antibacterial and antibiofilm potential of sulfated polysaccharides extracted from green algae Chlamydomonas reinhardtii. Journal of Applied Microbiology, 127, 1004-1017.

36. Sirisha, V. L., Mahuya, S., \& D’Souza, S. J. (2014). Menadione-induced caspase dependent programmed cell death in the green chlorophyte Chlamydomonas reinhardtii. Journal of Phycology,50, 587-601.

37. Bradford, M. M. (1976). A rapid and sensitive method for the quantitation of microgram quantities of protein utilizing the principle of protein dye binding. Analytical Chemistry, 72, 248-254.

38. Bitter, T., \& Muir, H. M. (1962). A modified uronic acid carbazole reaction. Analytical Biochemistry,4, 330-334.

39. Biemer, J. J. (1973). Antimicrobial susceptibility testing by the Kirby-Bauer disc diffusion method. Annals of Clinical and Laboratory Science.,3(2), 135-140.

40. Zhou, Y., Kong, Y., Kundu, S., Cirillo, J. D., \& Liang, H. (2012). Antibacterial activities of gold and silver nanoparticles against Escherichia coli and Bacillus Calmette-Guerin. Journal of Nanobiotechnology, 10, 19.

41. Pinto, N. C. C., Silva, J. B., Menegati, L. M., Guedes, M. C. M. R., Marques, L. B., Silva, T. P. D., Melo, R. C. N., Souza-Fagundes, E. M., Salvador, M. J., Scio, E., \& Fabri, R. L. (2017). Cytotoxicity and bacterial membrane destabilization induced by Annona squamosa L. extracts. Anais da Academia Brasileira de Ciências, 89, 2053-2073.

42. Bazargani, M. M., \& Jens, R. (2015). Anti-biofilm activity of essential oils and plant extracts against Staphylococcus aureus and E. coli biofilms. Food Control,61, 156-164.

43. Wang, J., Liu, H., Zhao, J., Gao, H., Zhou, L., Liu, Z., et al. (2010). Antimicrobial and Antioxidant activities of root bark essential oil of Periploca sepium and its main component 2-hydroxy 4-methoxybenzaldehyde. Molecules, 15, 5807-5817.

44. Graziano, T. S., Graziano, T. S., Cuzzullin, M. C., Franco, G. C., Schwartz-Filho, H. O., de Andrade, E. D., Groppo, F. C., \& Cogo-M€uller, K. (2015). Statins and antimicrobial effects: Simvastatin as a potential drug against Staphylococcus aureus biofilm. PLoS ONE,10, e0128098. https:// doi.org/10.1371/journal.pone.0128098

45. Pompilio, A., Piccolomini, R., Picciani, C., D’Antonio, D., Savini, V., \& Di Bonaventura, G. (2008). Factors associated with adherence to and biofilm formation on polystyrene by Stenotrophomonas maltophilia: The role of cell surface hydrophobicity and motility. FEMS Microbiology Letters, 287, 41-47.

46. Sorongon, M. L., Bloodgood, R. A., \& Burchard, R. P. (1991). Hydrophobicity, adhesion, and surface-exposed proteins of gliding bacteria. Applied Environmental Microbiology,57, 3193-3199.

47. Geier, H., Mostowy, S., Cangelosi, G. A., Behr, M. A., \& Timothy, E. F. (2008). Autoinducer-2 triggers the oxidative stress response in Mycobacterium avium, leading to biofilm formation. Applied Environmental Microbiology,74, 1798-1804.

48. Venkadesaperumal, G., Chetan Kumar, M., Ayaluru, M., \& Prathapkumar, H. S. (2016). Petunidin as a competitive inhibitor of acylated homoserine lactones in Klebsiella pneumoniae. RSC Adv, 6 , 2592-2601.

49. Wang, D., Jin, Q., Xiang, H., Wang, W., Guo, N., Zhang, K., et al. (2011). Transcriptional and functional analysis of the effects of magnolol: inhibition of autolysis and biofilms in Staphylococcus aureus. PLoS One, 6,.

50. Kearns, D. B. (2010). A field guide to bacterial swarming motility. Nature Reviews of Microbiology,8, 634-644. https://doi.org/10.1038/nrmicro2405

51. Sethupathy, S., Sathiyamoorthi, E., Kim, Y.-G., Lee, J.-H., \& Lee, J. (2020). Antibiofilm and antivirulence properties of indoles against Serratiamarcescens. Frontier Microbiology,11, 2637. https://doi.org/10.3389/fmicb.2020.584812 
52. Vinoj, G., Esakkirajan, M., Vijayan, S. R., Vaseeharan, B., Gopinath, S. (2020). Influence of $\mathrm{N}$-acylhomoserine lactonase silver nanoparticles on the quorum sensing system of Helicobacter pylori: A potential strategy to combat biofilm formation. Journal of Basic Microbiology. https:// doi.org/10.1002/jobm.201900537

53. MacFaddin, J. (1980). Biochemical tests for identification of medical bacteria (2nd ed.). Williams and Wilkins: Baltimore.

54. Slater, H., Crow, M., Everson, L., \& Salmond, G. P. C. (2003). Phosphate availability regulates biosynthesis of two antibiotics, prodigiosin and carbapenem, in Serratia via both quorum-sensingdependent and -independent pathways. Molecular Microbiology,47, 303-320. https://doi.org/10. 1046/j.1365-2958.2003.03295.x

55. Yan, V., Gu, S., Shi, Y., Cui, X., Wen, S., \& Ge, J. (2017). The effect of emodin on Staphylococcus aureus strains in planktonic form and biofilm formation in vitro. Archives in Microbiology, 199, 1267-1275.

56. Panigrahi, G. P., Rane, V., Vavilala, S. L., \& Choudhary, S. (2019). Deciphering the anti-Parkinson's activity of sulfated polysaccharides from Chlamydomonas reinhardtii on the $\alpha$-synuclein mutants A30P, A53T, E46K, E57K and E35K. Journal of Biochemistry, 166, 463-474.

57. Global Asthma Report. Auckland. (2014). Global asthma network. Available from: http://www. globalasthmareport.org/resources/Global_Asthma_Report_2014.pdf

58. Pneumonia: The forgotten killer of children. Geneva, The United Nations Children's Fund (UNICEF)/ World Health Organization (WHO), (2006). Available from: http://www.who.int/mater nal_child_adolescent/documents/9280640489/en/

59. Global Tuberculosis Report. (2016). Geneva, World Health Organization, Available from: http:// www.who.int/tb/publications/global_report/en/

60. Torre, L. A., Bray, F., Siegel, R. L., Ferlay, J., Lortet-Tieulent, J., \& Jemal, A. (2015). Global cancer statistics, 2012. CA: ACancer Journal for Clinicians, 65, 87-108.

61. Pearce, N., Ait-Khaled, N., Beasley, R., Mallol, J., Keil, U., Mitchell, Ed., \& Robertson, C. (2007). Worldwide trends in the prevalence of asthma symptoms: phase III of the International study of asthma and allergies in childhood (ISAAC). Thorax,62, 758-766.

62. Global Status Report on Noncommunicable Diseases. Geneva, World Health Organ. (2014). Available from: http://www.who.int/nmh/publications/ncd-status-report-2014/en/

63. GBD. (2016). Mortality and causes of death collaborators. Global, regional, and national life expectancy, allcause mortality, and cause-specific mortality for 249 causes of death, 1980-2015: A systematic analysis for the Global Burden of Disease Study 2015. Lancet,388, 1459-1544.

64. From burden to "best buys": reducing the economic impact of non-communicable disease in lowand middle-income countries. (2011). Geneva, World Health Organization. Available from: http:// www.who.int/nmh/publications/best_buys_summary/en/

65. Muhsin, J., Tasneem, U., Tahir, H., \& Saadia, A. (2015). Bacterial biofilm: Its composition, formation and role in human infections. Journal of Microbiology and Biotechnology, e-ISSN:2320-3528.

66. Randall, D., \& Garth, D. (2008). Biofilms and chronic infection: American Medical Association. JAMA, 299, 2682-2684.

67. Xu, S. Y., Huang, X., \& Cheong, K. L. (2017). Recent advances in marine algae polysaccharides: Isolation, structure, and activities. Marine Drugs, 15, 388. https://doi.org/10.3390/md15120388

68. Pane, G., Cacciola, G., Giacco, E., Mariottini, G., \& Coppo, E. (2015). Assessment of the antimicrobial activity of algae extracts on bacteria responsible of external otitis. Marine Drugs,13, 6440-6452.

69. Joon, Y., Min, J., In-Hak, J., Koji, Y., Yuji, K., \& Byoung-Mok, K. (2018). Antimicrobial and antibiofilm activities of sulfated polysaccharides from marine algae against dental plaque bacteria. Marine Drug,16, 301.

70. Patel, S. (2016). Therapeutic importance of sulfated polysaccharides from seaweeds: Updating the recent findings. 3 Biotech,2, 171-185.

71. Emer, S., \& Abu-Ghannam, N. (2016). Antibacterial derivatives of marine algae: An overview of pharmacological mechanisms and applications. Marine Drug,14, 81 .

72. Rendueles, O., Kaplan, J. B., \& Ghigo, J. M. (2013). Antibiofilm polysaccharides. Environmental Microbiology, 15, 334-346.

73. Vishwakarma, J., \& Sirisha, V. L. (2020). Unraveling the anti-biofilm potential of green algal sulfated polysaccharides against Salmonella enterica and Vibrio harveyi. Applied Microbiology and Biotechnology, 104(14), 6299-6314.

74. Kim, Y., Oh, S., \& Kim, S. H. (2009). Released exopolysaccharide (r-EPS) produced from probiotic bacteria reduce biofilm formation of enterohemorrhagic Escherichia coli O157:H7. Biochemical and Biophysics Research Communication, 379, 324-329. 
75. Wittschier, N., Lengsfeld, C., Vorthems, S., Stratmann, U., Ernst, J. F., Verspohl, E. J., \& Hensel, A. (2007). Large molecules as anti-adhesive compounds against pathogens. Journal of Pharmacy and Pharmacology,59, 777-786.

76. Zinger-Yosovich, K. D., \& Gilboa-Garber, N. (2009). Blocking of Pseudomonas aeruginosa and Ralstonia solanacearum lectins by plant and microbial branched polysaccharides used as food additives. Journal of Agricultural Food Chemistry,57, 6908-6913.

77. Montanaro, L., Poggi, A., Visai, L., Ravaioli, S., Campoccia, D., Speziale, P., \& Arciola, C. R. (2011). Extracellular DNA in Biofilms. The International Journal of Artificial Organs, 34, 824-831.

78. Norton, T. A., Thompson, R. C., Pope, J., Veltkamp, C. J., Banks, B., Howards, V., \& Hawkins, S. J. (1998). Using confocal laser scanning microscopy, scanning electron microscopy and phase contrast light microscopy to examine marine biofilms. Aquatic Microbial Ecology, 16, 199-204.

79. Hannig, C., Follo, M., Hellwig, E., \& Al-Ahmad, A. (2010). Visualization of adherent micro-organisms using different techniques. Journal of Medicinal Microbiology,59, 1-7.

80. Jacques, M., Lebrun, A., Foiry, B., Dargis, M., \& Malouin, F. (1991). Effects of antibiotics on the growth and morphology of Pasteurella multocida. Journal of General Microbiology,137, 2663-2668.

81. Gomes, L. C., \& Mergulhão, F. J. (2017). SEM analysis of surface impact on biofilm antibiotic treatment. Scanning. 2017https://doi.org/10.1155/2017/2960194

82. Smith, R. S., \& Iglewski, B. H. (2003). Pseudomonas aeruginosa quorum sensing as a potential antimicrobial target. Journal of Clinical Investigations, 112, 1460-1465.

83. Sepahi, E., Tarighi, S., Ahmadi, F. S., \& Bagheri, A. (2015). Inhibition of quorum sensing in Pseudomonas aeruginosa by two herbal essential oils from Apiaceae family. Journal of Microbiology,53, 176-180. https://doi.org/10.1007/s12275-015-4203-8

84. Taha, M. N., Saafan, A. E., Ahmedy, A., Gebaly, E. E., \& Khairalla, A. S. (2019). Two novel synthetic peptides inhibit quorum sensing-dependent biofilm formation and some virulence factors in Pseudomonas aeruginosa PAO1. Journal of Microbiology,57, 618-625. https://doi.org/10.1007/ s12275-019-8548-2

85. Ojo-Fakunle,, V. T., Woertman, J., Veldhuizen, E. J., \& Burt, S. A. (2013). Sub-lethal concentrations of carvacrol (from oregano) inhibit bacterial quorum sensing and formation of biofilms. Planta Medica, 79 - SL51. https://doi.org/10.1055/s-0033-1351877

86. Rutherford, S. T., \& Bassler, B. L. (2012). Bacterial quorum sensing: Its role in virulence and possibilities for its control. Cold Spring Harbor Perspect Med, 2, a012427.

87. Kociolek, M. G. (2009). Quorum-sensing inhibitors and biofilms. Anti-infective Agents in Medicinal Chem, 8, 315-326.

88. Riemann, H., Himathongkham, S., Willoughby, D., Tarbell, R., \& Breitmeyer, R. (1998). A survey for Salmonella by drag swabbing manure piles in California egg ranches. Avian Diseases,42, 67-71.

89. Hisham, A. (2013). Ambroxol blocks swarming and swimming motilities and inhibits biofilm formation by Proteus mirabilis isolated from diabetic foot infection. Asian Journal of pharmaceutical Technology and Innovation, 3, 109-116.

Publisher's note Springer Nature remains neutral with regard to jurisdictional claims in published maps and institutional affiliations. 